\title{
KUALITAS PELAYANAN SEBAGAI DETERMINAN KEPUASAN PELANGGAN JASA TRANSPORTASI GRAB BIKE DI YOGYAKARTA
}

\author{
Fajar Ramadhan \\ fajarramadhankasman28@gmail.com \\ Universitas Ahmad Dahlan \\ Hendro Setyono \\ hendro.setyono@yahoo.com \\ Universitas Ahmad Dahlan
}

\begin{abstract}
ABSTRAK
This research aims to analyze the influence of the quality of service of customer satisfaction on service businesses Grab-Bike transport in Yogyakarta. This research uses the five independent variables i.e. tangible, reliability, responsiveness, assurance and emphaty with one dependent variable i.e. consumer satisfaction. After a review of the literature as well as field and preparation of the hypothesis, the data in this study were collected through the dissemination of a questionnaire to 70 people who never use the Grab-Bike transport as research samples. Sampling technique used is a Non probability sampling method sampling incidental. Methods of data analysis used is the quantitative analysis that is test validity and reliability, multiple linear regression analysis, $t$ test and F-test as well as the coefficient of determination. Based on data analysis, the results showed that the indicators on research is valid and reliability. Hypothesis test on tangible, responsiveness, assurance and emphaty no effect significantly to consumer satisfaction. Hypothesis test of reliability has a positive and significant influence toward customer satisfaction.
\end{abstract}

Keywords: Tangible, responsiveness, reliability, assurance, emphaty and customer satisfaction.

\section{PENDAHULUAN}

Transportasi merupakan sarana yang sangat dibutuhkan pada zaman sekarang, karena dengan adanya transportasi dapat memilih jalur darat untuk memenuhi kebutuhannya. Ketergantungan masyarakat tehadap transportasi sangat tinggi, dengan alasan untuk mempersingkat waktu perjalanan. Kemajuan yang sangat pesat di bidang teknologi informasi memberikan pengaruh yang besar terhadap berbagai aspek kehidupan manusia. Pengaruh yang paling nyata terlihat pada perubahan mendasar terhadap cara orang melakukan transaksi, terutama dalam dunia bisnis. Salah satu hasil kemajuan
\end{abstract}

teknologi informasi yang berkontribusi besar terhadap perubahan ini adalah internet. Internet adalah suatu jaringan yang dipasangkan dengan alat komunikasi sehingga kita bisa berinteraksi dimanapun dan kapanpun. Dengan adanya internet, cara perusahaan melakukan transaksi berubah, dari cara lama yang prosesnya mengorbankan waktu dan biaya yang besar menjadi proses yang lebih cepat dan lebih mudah.

Era perkembangan internet di tengah-tengah pertumbuhan penduduk yang begitu pesat, internet sangat dibutuhkan untuk memenuhi kebutuhan masyarakat. Kehadiran jasa transportasi berbasis aplikasi online yang 
menggunakan internet sangat berpengaruh bagi masyarakat dalam segala aktifitas secara cepat dan efisien. Lupiyoadi (2014) jasa merupakan semua aktivitas ekonomi yang hasilnya bukan berbentuk produk fisik atau konstruksi, yang umumnya dihasilkan dan dikonsumsi secara bersamaan serta memberikan nilai tambah (misalnya kenyamanan, hiburan, kesenangan, atau kesehatan) konsumen. Belum lama ini muncul sebuah terobosan baru dalam hal transportasi umum, yaitu jasa ojek online yang bisa dipesan melalui smartphone/telpon genggam kita. Sistem ojek online ini sangat berbeda dengan ojek-ojek dahulu, dimana kita harus mencari di jalan secara manual atau mendatangi ke pangkalan ojek. Tarif yang ditetapkan oleh ojek pangkalan pun tinggi dan harus ditawar beberapa lama baru dapat turun, yang jelas memakan waktu dan biaya. Tapi di ojek online ini masyarakat hanya tinggal menginstall aplikasi yang sudah di sediakan oleh perusahaan ojek onlinelalu dengan memilih menu y ang tersedia kita sudah dapat melihat ojek onlineyang ada di sekitar tempat kita berada, jadi dapat langsung diposisikan dengan yang terdekat sehingga dapat cepat menjemput kita. Pelanggan dapat menentukan tempat penjemputan dan tempat pengantaran, kemudian muncul tarif yang perlu dibayar untuk layanan ini berdasarkan jarak kilometer.bukan hanya untuk sarana transportasi saja ojek online ini juga dapat kita gunakan untuk keperluan membeli makanan/mengambil barang-barang kita di suatu tempat.

Dinamika persaingan bisnis jasa pada saat ini mengharuskan setiapperusahaan yang bergerak dibidang ini untuk senantiasa melakukan berbagai strategi agar dapat merebut hati konsumen. Dengan bermunculan berbagai masalah transportasi, semakin banyak pula bisnis sektor jasa transportasi yang berpeluang untuk berbisnis, seperti bisnis dalam skala besar taxi, bus sampai skala kecil becak motor, angkot ataupun ojek pangkalan. Untuk memenuhi kebutuhan akan jasa transportasi tersebut, perlu adanya penyedia jasa yang memberikan pelayanan yang baik dan inovatif. Inovasi bukanlah hanya sekedar proses penciptaan sesuatu yang baru, tetapi juga merupakan produk aktual atau outcome (hasil). Bagi bisnis penghasil jasa, outcome bukan hasil output, akan tetapi modifikasi dari pelayanan yang sudah ada. Sehingga perusahaan jasa transportasi membuat inovasi yang mempermudah masyarakat serta mempersingkat waktu perjalanan.

Jasa transportasi yang memiliki pelayanan yang cepat dari segi komunikasi untuk pemesanan, sehingga masyarakat lebih memilih jasa tersebut karena cukup mudah dan cepat. Untuk mendapatkan loyalitas para pelanggan perusahaan harus memiliki strategi pemasaran yang baik dan tepat agar mempengaruhi loyalitas pelanggannya. Faktor-faktor yang mempengaruhi loyalitas pelanggan dalam menggunakan jasa transportasi, diantaranya adalah kualitas pelayanan. Kualitas layanan merupakan salah satu bagian dari strategi manajemen pemasaran. Kualitas pelayanan telah menjadi satu tahap faktor dominan terhadap keberhasilan suatu organisasi persaingan antar perusahaan, kamajuan teknologi, tahapan perekonomian dan sosial budaya masyarakat. Kualitas pelayanan menjadi suatu keharusan yang harus dilakukan perusahaan agar dapat mampu bertahan dan tetap mendapat kepercayaan pelanggan. Menurut Lupiyoadi (2013) mengatakan bahwa kualitas pelayanan yaitu seberapa jauh perbedaan antara 
kenyataan dan harapan pelanggan atas pelayanan yang mereka terima.

Loyalitas pelanggan juga dapat terbentuk dari kepuasan yang dirasakan adalah perasaan senang ataupun kecewa yang muncul setelah menggunakan jasa tersebut. Pelanggan akan merasa senang dan kecewa setelah membandingkan kinerja atau hasil produk yang difikirkan terhadap kinerja (hasil) yang diharapkan. Dalam artian lain, seseorang merasa puas apabilah hasil yang didapat minimal mampu memenuhi harapannya sedangkan seseorang merasa tidak puas apabila hasil yang didapat tidak mampu memenuhi harapannya. Kepuasan yang dirasakan seseorang akan memberikan dampak terhadap perilaku pengguna kembali secara terus-menerus sehingga terbentuklah loyalitas. Lupiyoadi (2013) kepuasan merupakan tingkat perasaan di mana seseorang menyatakan hasil perbandingan atas kinerja produk jasa yang diterima dengan yang diharapkan.

Pada saat ini industri jasa transportasi online semakin marak di Indonesia. Salah satunya perusahaan Grab yang merupakan salah satu badan usaha yang mengkonsentrasikan salah satu bidang usahanya di sektor industri jasa yaitu aplikasi penyedia transportasi. Grab (sebelumnya dikenal sebagai GrabTaxi) merupakan salah satu platform yang bermarkas si Singapura dan paling sering di gunakan di Asia Tenggara. Grab didirikan oleh Anthony Tan dan Tan Hooi Ling pada bulan juni 2012 (dikenal sebagai GrabTaxi hingga 2016).Saat ini Grab menyediakan layanan di Singapura, Indonesia, Filipina, Malaysia, Thailand, Vietnam, Myanmar, dan Kamboja. Grab yakin bahwa disetiap masyarakat di Asia tenggara harus mendapatkan keuntungan dari ekonomi digital, dan perusahaan memberikan akses untuk layanan transportasi yang aman dan terjangkau, layanan pesan antar makanan dan pengiriman barang, serta layanan pembayaran mobile dan finansial.

Aplikasi penyedia transportasi adalah sebuah aplikasi yang umumnya digunakan pada ponsel cerdas atau smartphone dengan fungsi sebagai alat pemesanan kendaraan untuk keperluan transportasi dari suatu tempat ke tempat lain melalui situs online atau menginstal aplikasi tersebut dan melakukan pemesanan transportasi melalui smartphone yang terhubung dengan jaringan internet. Kendaraan yang dipesan melalui aplikasi penyedia transportasi dapat berupa taksi, mobil, atau ojek.

Aplikasi Grab juga dapat diunduh pada smartphone yang memiliki sistem operasi iOS atau pun Android. Dengan menggunakan aplikasinya di smartphone pelanggan dapat diantar dan dijemput sesuai tujuan. Selain itu PT.Grab Indonesia juga mengembangkan layanan aplikasi seperti GrabTaxi, GrabCar, GrabShare, GrabBike, GrabExpress, GrabFood. Barubaru ini Grab meluncurkan layanan GrabGerak, sebuah solusi unik yang pertam kali disediakan untuk mendukung para penyandang disabilitas untuk bergerak dan mendapatkan lebih banyak akses dalam menjalankan aktivitas seharihari. Dalam penelitian ini hanya mengambil pada jasa layanan GrabBike karena pada layanan GrabBike pelanggan dapat merasakan layanan mulai dari pemesanan hinggah sampai ke tempat tujuan.

Kehadiran Grab-Bike saat ini sangatlah mengikuti perkembangan teknologi, karena Grab-Bike memiliki konsekuensi yang mendukung pernyataannya tersebut yakni:

1. Cepat, Cepat melintasi kemacetan dengan menggunakan kendaraan roda dua. 
2. Aman, Biker terdaftar dan berlisensi dengan atribut lengkap serta catatan perjalanan yang transparan.

3. Pasti, Tidak perlu lagi tawar menawar karena biaya perjalanan pasti.

Tujuan dari penelitian ini adalah: 1) untuk mengetahui bukti fisik (tangible) berpengaruh signifikan terhadap kepuasan pelanggan GrabBike di Yogyakarta, 2) untuk mengetahui kehandalan (reliability) berpengaruh signifikan terhadap kepuasan pelanggan GrabBike di Yogyakarta, 3) untuk mengetahui daya tanggap (responsiveness) berpengaruh signifikan terhadap kepuasan pelanggan GrabBike di Yogyakarta, 4) untuk mengetahui jaminan (assurance) berpengaruh terhadap kepuasan pelanggan GrabBike di Yogyakarta, 5) untuk mengetahui empati (empathy) berpengaruh signifikan terhadap kepuasan pelanggan GrabBike di Yogyakarta dan 6) untuk mengetahuikualitas pelayanan secara simultan berpengaruh terhadap kepuasan pelanggan GrabBike di Yogyakarta.

\section{REVIEW LITERATUR DAN HIPOTESIS}

\section{Landasan Teori}

1. Jasa

Menurut Kotler dan keller (2012) jasa merupakan setiap aktifitas, manfaat atau performance yang ditawarkan oleh satu pihak ke lain yang bersifat intangible dan tidak menyebabkan perpindahan kepemilikan apapun dimana dalam produksinya dapat terikat maupun tidak dengan produk fisik.

2. Kualitas Layanan

Menurut Kotler dan Amstrong (2012) pelayanan setiap tindakan kinerja yang salah satu pihak dapat menawarkan yang lain yang intinya intangible dan tidak mengakibatkan kepemilikan apapun yang produksi mungkin atau mungkin tidak terikat produk fisik. Lupiyoadi (2013) menambahkan bahwa kualitas pelayanan yaitu seberapa jauh perbedaan antara kenyataan dan harapan pelanggan atas pelayanan yang mereka terima.

3. Kepuasan Pelanggan

Daryanto dan Setyobudi (2014) mengatakan kepuasan konsumen adalah suatu penilaian emosional dari konsumen setelah konsumen menggunakan produk dimana harapan dan kebutuhan konsumen yang menggunakannya terpenuhi.

\section{Penelitian Terdahulu}

Andreani (2010) melakukan penelitian dengan judul analisa kualitas layanan bisnis makanan dan minuman di Surabaya ditinjau dari derajat pemenuhan kepuasan konsumen. Hasilnya kelima dimensi kualitas pelayanan terbukti berpengaruh signifikan dan positif terhadap variabel kepuasan pelanggan.

Marismiati (2013) melakukan penelitian dengan judul pengaruh kualitas pelayanan terhadap kepuasan pelanggan jasa BRT Transmusi Palembang. Hasilnya Variabel tangible, reliability, dan emphaty tidak berpengaruh signifikan. Variabel responsiveness dan assurance berpengaruh signifikan terhadap kepuasan penumpang.

\section{Hipotesis}

H1: Bukti fisik berpengaruh positif terhadap kepuasan pelanggan.

$\mathrm{H} 2$ : Kehandalan berpengaruh positif terhadap kepuasan pelanggan.

H3: Daya tanggap berpengaruh positif terhadap kepuasan konsumen.

H4: Jaminan berpengaruh positif terhadap kepuasan pelanggan.

H5: Empati berpengaruh positif terhadap kepuasan pelanggan. 
H6: Bukti fisik, kehandalan, daya tanggap, jaminan, empati berpengaruh secara simultan terhadap kepuasan pelanggan.

\section{METODE PENELITIAN}

\section{Populasi dan Sampel}

Menurut Sugiyono (2010) populasi adalah wilayah generalisasi yang terdiri atas obyek/subyek yang mempunyai kualitas dan karakteristik tertentu yang ditetapkan oleh peneliti untuk dipelajari dan kemudian ditarik kesimpulannya. Populasi dalam penelitian ini adalah seluruh pelanggan yang pernah menggunakan jasa transportasi Grab-Bike di Yogyakarta, dengan asumsi jumlah dalam penelitian ini bahwa jumlah populasi tidak terbatas.

Sugiyono (2010) sampel adalah bagian dari jumlah dan karakteristik yang dimiliki oleh populasi tersebut. Bila populasi besar, dan peneliti tidak mungkin mempelajari semua yang ada pada populasi, misalnya karena keterbatasan dana, tenaga dan waktu, maka peneliti dapat menggunakan sampel yang diambil dari populasi itu. Sampel dalam penelitian ini adalah masyarakat Yogyakarta yang menggunakan jasa Grab-Bike.

Teknik pengambilan menggunakan teknik Purposive Sampling dan Incidental Purposive Sampling, yaitu teknik untuk menentukan sampel penelitian dengan beberapa pertimbangan tertentu yang bertujuan agar data yang diperoleh nantinya bisa lebih representatif (Sugiyono, 2010). Sampling incidental adalah teknik pengambilan sampel berdasarkan kebetulan bertemu dengan peneliti dapat digunakan sebagai sampel. Adapun kriteria dalam pengambilan sampel adalah:

1. Pria dan wanita minimal usia 17 keatas.

2. Masyarakat di kota Yogyakarta.

3. Mempunyai aplikasi Grab.

4. Pernah menggunakan jasa Grab-Bike lebih dari 1 kali

\section{Definisi Operasional}

Variabel dependen dalam penelitian ini adalah kepuasan pelanggan (Y), sementara vaariabel independen yang digunakan adalah kualitas pelayanan (X). Kualitas pelayanan artinya perbandingan antara persepsi konsumen atas pelayanan yang mereka dapatkan dengan layanan yang sesungguhnya, yang mereka harapkan dan inginkan. Terdapat lima indikator kualitas pelayanan yang akan diteliti dalam penelitian ini, yaitu tangible (bukti langsung), reliability (keandalan), responsiveness (daya tanggap), assurance (jaminan) dan empathy (empati).

\section{Uji Instrumen}

1. Uji Validitas

Sugiyono (2014) menyatakan bahwa instrumen yang valid berarti alat ukur yang digunakan untuk mendapatkan data (mengukur) itu valid. Valid berarti instrumen tersebut dapat digunakan untuk mengukur apa yang seharusnya diukur. Kuesioner dikatakan valid jika jika pertanyaan pada kuesioner mampu mengungkapkan sesuatu yang diukur oleh kuesioner tersebut. Alat uji validitas dalam penelitian ini adalah Confirmatory Factor Analisis (CFA) dengan nilai faktor loading lebih besar dari 0,5 dikatakan valid, untuk memudahkan dalam melakukan uji validitas, maka digunakan analisis faktor yang ada pada program komputer SPSS.

\section{Uji Reliabilitas}

Menurut Sugiyono reliabilitas berkenaan dengan derajat konsistensi dan stabilitas data atau temuan. Karena reliabilitasberkenaan dengan derajad konsistensi, maka 
bila ada peneliti lain mengulangi atau mereplikasi dalam penelitian pada obyek yang sama dengan metode yang sama maka akan menghasilkan data yang sama pula. Untuk melihat andal tidaknya suatu alat ukur digunakan pendekatan secara statistika, yaitu melalui koefisien reliabilitas dan apabila Cronbach Alpha lebih besar dari 0,6 maka secara keseluruhan pernyataan tersebut dinyatakan andal (reliabel).

\section{Teknik Analisis Data}

1. Analisis Regresi Berganda

Regresi berganda yaitu untuk menganalisis seberapa besar pengaruh antara beberapa variabel independen. Model ini digunakan untuk mengetahui tentang pengaruh variabel tangible $(\mathrm{X} 1)$, reliability $(\mathrm{X} 2)$, responsiveness (X3), assurance (X4), empathy (X5) dan kepuasan konsumen (Y). Bentuk umum persamaan regresi berganda adalah sebagai berikut:

$\mathrm{y}=\mathrm{a}+\mathrm{b} 1 \mathrm{X} 1+\mathrm{b} 2 \mathrm{X} 2+\mathrm{b} 3 \mathrm{X} 3+\mathrm{b} 4 \mathrm{X} 4$ $+\mathrm{b} 5 \times 5$

Keterangan :

$\mathrm{y}=$ Kepuasan Pelanggan

$\mathrm{a}=$ Konstanta

$\mathrm{X} 1$ = Tangible

$\mathrm{X} 2$ = Reliability

$\mathrm{X} 3$ = Responsiveness

$\mathrm{X} 4$ = Assurance

$\mathrm{X} 5$ = Empathy

\section{Uji Hipotesis}

1. Uji Parsial (Uji T)

Uji t bertujuan untuk mengetahui besarnya pengaruh masing-masing variabel independen (tangible, reablility, responsiveness, assurance dan empathy) terhadap variabel dependen yaitu (kepuasan konsumen).
Dalam penelitian ini digunakan taraf signifikansi sebesar 5\% dan derajat kebebasan (d.f) $=\mathrm{n}-\mathrm{k}$, dapat diketahui dari hasil perhitungan computer program SPSS. Kesimpulan yang diambil adalah:

Jika $\mathrm{t}$ hitung $>\mathrm{t}$ tabel tabel pada alpha $=$ 5\%, maka Ho ditolak dan $\mathrm{Ha}$ diterima, artinya variabel independen secara parsial mempunyai pengaruh signifikan terhadap variabel dependen.

Jika $\mathrm{t}$ hitung $<\mathrm{t}$ tabel tabel pada alpha $=5 \%$, maka Ho diterima dan $\mathrm{Ha}$ ditolak, artinya variabel independen secara parsial tidak mempunyai pengaruh signifikan terhadap variabel dependen.

\section{Uji Simultan (Uji F)}

Pengujian ini dimaksudkan untuk mengetahui apakah kelima variabel tersebut sama-sama mempunyai pengaruh signifikan dengan kepuasan konsumen. Dalam pengujian ini digunakan taraf signifikansi sebesar 5\% dan derajat kebebasan (d.f) $=(\mathrm{k}-1, \mathrm{n}$ $\mathrm{k}, \alpha$ ), dapat diketahui dari hasil perhitungan computer program SPSS. Kesimpulan yang diambil adalah:

Jika f hitung $>$ f tabel tabel pada $\alpha=5 \%$ , maka Ho ditolak dan $\mathrm{Ha}$ diterima, sebaliknya

Jika $\mathrm{f}$ hitung $<\mathrm{f}$ tabel tabel pada $\alpha=$ $5 \%$, maka Ho diterima dan Ha ditolak, dengan $\mathrm{F}$ tabel derajat kebebasan $=(\mathrm{k}$ $1, \mathrm{n}-\mathrm{k}, \alpha)$.

\section{Uji Koefisien Determinasi}

Koefisien determinasi (R2) sering disebut juga sebagai koefisien determinasi majemuk adalah untuk mengukur seberapa jauh kemampuan model dalam menerangkan variasi variabel dependent. Nilai koefisien 
determinasi adalah antara 0 dan 1 . Nilai R2 yang kecil menunjukkan kemampuan variabel independen dalam menjelaskan variasi variabel dependen yang sangat terbatas (Sanusi 2014).

Nilai yang mendekati 1 berarti variabel-variabel independen memberikan hampir semua informasi yang dibutuhkan untuk memprediksi variasi dependen. Uji determinasi dilakukan untuk melihat besarnya pengaruh kualitas pelayanan terhadap kepuasan pelanggan pada bisnis jasa transportasi Grab-Bike.

\section{HASIL PENELITIAN DAN PEMBAHASAN}

\section{Hasil Analisis Responden}

\begin{tabular}{|c|c|c|c|c|}
\hline No & \multicolumn{2}{|c|}{ Keterangan } & Frekuensi & Presentase \\
\hline \multirow[t]{2}{*}{1.} & Jenis Kelamin & $\begin{array}{l}\text { 1. Laki-laki } \\
\text { 2. Perempuan }\end{array}$ & $\begin{array}{l}26 \\
34\end{array}$ & $\begin{array}{l}43,3 \\
56,7\end{array}$ \\
\hline & Total & & 60 & 100 \\
\hline \multirow[t]{2}{*}{2.} & Umur & $\begin{array}{l}\text { 1. } 17-24 \text { tahun } \\
\text { 2. } 24-32 \text { tahun } \\
\text { 3. Diatas } 32 \text { tahun }\end{array}$ & $\begin{array}{l}44 \\
12 \\
4\end{array}$ & $\begin{array}{l}73,3 \\
20,0 \\
6,7\end{array}$ \\
\hline & Total & & 60 & 100 \\
\hline \multirow[t]{2}{*}{3} & Pekerjaan & $\begin{array}{l}\text { 1. } \\
\text { Pelajar/Mahasiswa } \\
\text { 2. PNS } \\
\text { 3. Wiraswasta }\end{array}$ & $\begin{array}{l}38 \\
5 \\
12\end{array}$ & $\begin{array}{r}63,3 \\
8,3 \\
28,3\end{array}$ \\
\hline & Total & & 60 & 100 \\
\hline \multirow[t]{2}{*}{4} & $\begin{array}{l}\text { Menggunakan } \\
\text { jasa Grab-Bike }\end{array}$ & $\begin{array}{l}1.2 \text { kali } \\
\text { 2. Lebih dari } 2\end{array}$ & $\begin{array}{l}8 \\
52\end{array}$ & $\begin{array}{l}13,3 \\
86,7\end{array}$ \\
\hline & Total & & 60 & 100 \\
\hline
\end{tabular}

Berdasarkan tabel di atas, menunjukan responden dalam penelitian ini adalah responden dengan jenis kelamin dari 60 responden terdiri dari perempuan sebanyak 34 orang atau $56,7 \%$ dan laki-laki 26 orang atau 43,3\%. Hal ini karena sebagian penyebaran kuesioner lebih banyak pada perempuan.

Responden dalam penelitian ini dengan berusia 17-24 tahun sebanyak 44 orang atau 73,3\%, yang berusia 24-32 tahun sebanyak 12 atau $20,0 \%$, berusia di atas 32 tahun sebanyak 4 orang atau $6,7 \%$. Hal ini karena sebagian pelanggan merupakan pelajar/mahasiswa yang dominan menggunakan jasa transportasi ojek online Grab-Bike.

Pekerjaan responden yang dijadikan sampel terdiri dari pegawai negeri sipil sebanyak 5 orang atau 8,3\%, wiraswasta 12 orang atau $28,3 \%$, Pelajar/mahasiswa sebanyak 38 orang atau $63,3 \%$.

Jumlah menggunakan jasa ojek online Grab-Bike di Yogyakarta yaitu, 2 kali menggunakan ada 8 orang atau $13,3 \%$, lebih dari 2 kali ada sebanyak 52 orang atau $86,7 \%$. 


\section{Hasil Penelitian}

1. Hasil Uji Validitas

\begin{tabular}{|c|c|c|c|c|c|c|c|}
\hline \multirow[t]{2}{*}{ Variabel } & \multirow[t]{2}{*}{ Pertanyaan } & \multicolumn{6}{|c|}{ Komponen } \\
\hline & & 1 & 2 & 3 & 4 & 5 & 16 \\
\hline Tangible & $\begin{array}{l}1.1 \\
1.2 \\
1.3 \\
\end{array}$ & $\begin{array}{l}0,791 \\
0,822 \\
0,893\end{array}$ & & & & & \\
\hline Reliability & $\begin{array}{l}2.1 \\
2.2 \\
2.3 \\
2.4 \\
2.5 \\
2.6 \\
2.7 \\
2.8\end{array}$ & & $\begin{array}{l}0,707 \\
0,752 \\
0,770 \\
0,582 \\
0,505 \\
0,738 \\
0,773 \\
0,623\end{array}$ & & & & \\
\hline Responsiveness & $\begin{array}{l}3.1 \\
3.2 \\
3.3 \\
3.4 \\
3.5 \\
3.6 \\
3.7 \\
\end{array}$ & & & $\begin{array}{l}0,550 \\
0,826 \\
0,692 \\
0,917 \\
0,898 \\
0,599 \\
0,796\end{array}$ & & & \\
\hline Assurance & $\begin{array}{l}4.1 \\
4.2 \\
4.3 \\
4.4 \\
4.5 \\
4.6 \\
4.7 \\
\end{array}$ & & & & $\begin{array}{l}0,733 \\
0,448 \\
0,851 \\
0,797 \\
0,691 \\
0,769 \\
0,727\end{array}$ & & \\
\hline Empathy & $\begin{array}{l}5.1 \\
5.2 \\
5.3 \\
5.4 \\
5.5 \\
5.6 \\
\end{array}$ & & & & & $\begin{array}{l}0,889 \\
0,679 \\
0,663 \\
0,901 \\
0,799 \\
0,728 \\
\end{array}$ & \\
\hline $\begin{array}{l}\text { Kepuasan } \\
\text { Konsumen }\end{array}$ & $\begin{array}{l}6.1 \\
6.2 \\
6.3 \\
6.4 \\
6.5 \\
6.6 \\
6.7 \\
\end{array}$ & & & & & & $\begin{array}{l}0,890 \\
0,823 \\
0,708 \\
0,810 \\
0,741 \\
0,866 \\
0,524\end{array}$ \\
\hline
\end{tabular}

Berdasarkan tabel di atas, dapat diketahui semua butir pertanyaan dari 6 (Enam) variabel yang dinyatakan valid dan ada beberapa butir pertanyaan yang dibuang, karena nilai CFA sudah lebih besar 0,5. Menurut Ghozali (2011) kriteria atau syarat suatu item tersebut dinyatakan valid adalah diatas 0,5 dan tingkat signifikansi penelitian adalah berada dibawah 0,05 .
2. Hasil Uji Reliabilitas

\begin{tabular}{|c|c|c|c|}
\hline No & Variabel & $\begin{array}{c}\text { Croncbanch's } \\
\text { Alpha }\end{array}$ & Keterangan \\
\hline 1 & Tangible $\left(\mathrm{X}_{1}\right)$ & 0,772 & Reliabel \\
\hline 2 & Reliability $\left(\mathrm{X}_{2}\right)$ & 0,806 & Reliabel \\
\hline 3 & Responsiveness $\left(\mathrm{X}_{3}\right)$ & 0,858 & Reliabel \\
\hline 4 & Assurance $\left(\mathrm{X}_{4}\right)$ & 0,817 & Reliabel \\
\hline 5 & Empathy $\left(\mathrm{X}_{5}\right)$ & 0,866 & Reliabel \\
\hline 6 & Kepuasan Konsumen $(\mathrm{Y})$ & 0,875 & Reliabel \\
\hline
\end{tabular}

Dari tabel di atas maka hasil dari uji reliabilitas dapat dijelaskan sesuai dengan nilai Croncbanch's Alpha variabel. Berikut penjelasannya :

Tangible, nilai yang dihasilkan oleh variabel ini sebesar 0,772 dimana sesuai ketentuan nilai 0,772 lebih besar dari 0,60 sehingga hasil dari variabel tanggap dalam pengujian yaitu reliabel. Dalam variabel ini setiap butir pernyataan dan jawaban konsisten.

Reliability, nilai yang dihasilkan oleh variabel ini sebesar 0,806 dimana sesuai ketentuan nilai 0,806 lebih besar dari 0,60 sehinggah hasil dari variabel tanggap dalam pengujian yaitu reliabel. Dalam variabel ini setiap butir pertanyaan dan jawaban konsisten.

Responsiveness, nilai yang dihasilkan oleh variabel ini sebesar 0,858 dimana sesuai ketentuan nilai 0,858 lebih besar dari 0,60 sehinggah hasil dari variabel tanggap dalam pengujian yaitu reliabel. Dalam variabel ini setiap butir pertanyaan dan jawaban konsisten.

Assurance, nilai yang dihasilkan oleh variabel ini sebesar 0,817 dimana sesuai ketentuan nilai 0,817 lebih besar dari 0,60 sehinggah hasil dari variabel tanggap dalam pengujian yaitu reliabel. Dalam variabel ini setiap butir pertanyaan dan jawaban konsisten. 
Empathy, nilai yang dihasilkan oleh variabel ini sebesar 0,866 dimana sesuai ketentuan nilai 0,866 lebih besar dari 0,60 sehinggah hasil dari variabel tanggap dalam pengujian yaitu reliabel. Dalam variabel ini setiap butir pertanyaandan jawaban konsisten.

Kepuasan konsumen, nilai yang dihasilkan oleh variabel ini sebesar 0,875 dimana sesuai ketentuan nilai 0,875 lebih besar dari 0,60 sehinggah hasil dari variabel tanggap dalam pengujian yaitu reliabel. Dalam variabel ini setiap butir pertanyaan dan jawaban konsisten.

Berdasarkan analisis yang telah dilakukan dapat disimpulkan bahwa dari seluruh pertanyaan yang ada telah memenuhi ketentuan dengan memiliki nilai Croncbanch's Alpha lebih besar dari 0,60 yang menjadikan hasil dari variabel tangible, reliability, responsiveness, assurance, empathy, dan kepuasan konsumen dinyatakan reliabel. Variabel dependent dalam penelitian inipun memiliki nilai Croncbanch's Alpha 0,875 lebih besar dari 0,60. Sehingga dari variabelvariabel yang dinyatakan reliabel memiliki kekonsistensian antara pernyataan dan jawaban yang diberikan responden.
3. Hasil Uji Regresi Linier Berganda

\begin{tabular}{|c|c|}
\hline \multirow{2}{*}{ Model } & Unstandarized Coefisient \\
\cline { 2 - 2 } & $\mathrm{B}$ \\
\hline 1 (Constant) & 1,735 \\
\hline Tangible & 0,037 \\
\hline Reliability & 0,360 \\
\hline Responsiveness & 0,041 \\
\hline Assurance & 0,050 \\
\hline Empathy & 0,097 \\
\hline$\overline{\mathrm{Y}}=\mathbf{1}, 73 \overline{5}+0,037 \mathrm{~Tb}+0,360 \mathrm{Rb}+$ \\
$0,041 \mathrm{Rp}+0,050 \mathrm{Ar}+0,097 \mathrm{Ep}$
\end{tabular}

Berdasarkan persamaan tersebut, maka dapat dijelaskan sebagai berikut: a. Koefisien konstanta sebesar 1,735 artinya jika tidak ada variabel tangible, reliability, responsiveness, assurance, dan emphaty bernilai 0 , maka kepuasan konsumen bernilai sebesar 1,734 poin.

b. Koefisien regresi variabel tangible adalah 0,037 berarah positif, artinya setiap peningkatan pada kualitas bukti fisik sebesar 1 poin dan variabel lainnya tetap, maka kepuasan konsumen akan mengalami kenaikan sebesar 0,037 poin.

c. Koefisien regresi variabel reliability adalah 0,360 berarah positif, artinya setiap peningkatan pada kualitas kehandalan Grab-Bike sebesar 1 poin dan variabel lainnya tetap, maka kepuasan konsumen akan mengalami kenaikan sebesar 0,360 poin.

d. Koefisien regresi variabel responsiveness adalah 0,041 berarah positif, artinya setiap peningkatan pada kualitas daya tanggap sebesar 1 poin dan variabel lainnya tetap maka kepuasan konsumen akan mengalami kenaikan sebesar 0,041 poin. 
e. Koefisien regresi variabel assurance adalah 0,050 berarah positif, artinya setiap peningkatan pada kualitas jaminan sebesar 1 poin maka kepuasan konsumen akan mengalami kenaikan sebesar 0,050 poin.

f. Koefisien regresi variabel emphaty adalah sebesar 0,097 berarah positif, artinya setiap peningkatan pada kualitas kepedulian sebesar 1 poin maka kepuasan konsumen akan mengalami kenaikan sebesar 0,097 poin.

4. Hasil Uji Parsial (Uji T)

\begin{tabular}{|c|c|c|c|c|c|}
\hline \multirow[t]{2}{*}{ Model } & \multicolumn{2}{|c|}{$\begin{array}{l}\text { Unstandardized } \\
\text { Coefficients }\end{array}$} & \multirow{2}{*}{\begin{tabular}{|c|} 
Standardized \\
Coefficients \\
Beta \\
\end{tabular}} & \multirow[t]{2}{*}{$t$} & \multirow[t]{2}{*}{ Sig. } \\
\hline & B & Std.Error & & & \\
\hline $\begin{array}{l}1 \\
\text { (Constant) }\end{array}$ & 1,735 & 0,898 & & 1,932 & 0,059 \\
\hline Tangible & 0,037 & 0,104 & 0,044 & 0,357 & 0,722 \\
\hline Reliability & 0,360 & 0,134 & 0,360 & 2,629 & 0,009 \\
\hline Responsiveness & 0,041 & 0,121 & 0,045 & 0,334 & 0,739 \\
\hline Assurance & 0,050 & 0,202 & 0,036 & 0,246 & 0,807 \\
\hline Empathy & 0,097 & 0,123 & 0,106 & 0,788 & 0,434 \\
\hline
\end{tabular}

Hasil pengujian hipotesis secara parsial melalui uji $t$ diperoleh $t$ hitung berdasarkan nilai koefisien yang dapat dilihat pada gambar di atas menunjukkan bahwa:

a. Tangible atau bukti fisik tidak berpengaruh signifikan terhadap kepuasan konsumen pada bisnis jasa transportasi Grab-Bike dengan $\mathrm{t}$ hitung $<\mathrm{t}$ tabel sebesar $0,357<$ 2,005. Besar pengaruh bukti fisik terhadap kepuasan konsumen adalah $4,4 \%$. Hal ini bukan berarti bahwa bukti fisik tidak penting, akan tetapi bukti fisik tetap memiliki pengaruh namun tidak signifikan. Hasil pengujian $\mathrm{H} 1$ dalam penelitian ini yang menyatakan bahwa variabel tangible tidak berpengaruh signifikan terhadap kepuasan konsumen. Jadi dengan demikian H1 ditolak.

b. Reliability atau kehandalan berpengaruh signifikan terhadap kepuasan pelanggan pada bisnis jasa transportasi Grab-Bike dengan t hitung > t tabel sebesar 2,692 > 2,005 . Besar pengaruh kehandalan terhadap kepuasan konsumen adalah $3,6 \%$. Hasil pengujian $\mathrm{H} 2$ dalam penelitian ini menyatakan bahwa variabel reliability berpengaruh signifikan terhadap kepuasan pelanggan, dengan arah hubungan positif. Jadi dengan demikian $\mathrm{H} 2$ diterima.

c. Responsiveness atau daya tanggap tidak berpengaruh signifikan terhadap kepuasan pelanggan pada bisnis jasa transportasi Grab-Bike dengan $\mathrm{t}$ hitung $<\mathrm{t}$ tabel sebesar $0,334<2,005$. Besar pengaruh daya tanggap terhadap kepuasan konsumen adalah 4,5\%. Hasil pengujian $\mathrm{H} 3$ dalam penelitian ini yang menyatakan bahwa variabel responsiveness tidak berpengaruh signifikan terhadap kepuasan pelanggan. Jadi dengan demikian H3 ditolak.

d. Assurance atau jaminan tidak berpengaruh signifikan terhadap kepuasan pelanggan pada bisnis jasa transportasi Grab-Bike dengan $\mathrm{t}$ hitung $<\mathrm{t}$ tabel sebesar $0,246<$ 2,005. Besar pengaruh jaminan terhadap kepuasan pelanggan adalah 3,6\%. Hasil pengujian $\mathrm{H} 4$ dalam penelitian ini yang menyatakan bahwa variabel 
assurance tidak berpengaruh signifikan terhadap kepuasan pelanggan. Jadi dengan demikian H4 ditolak.

e. Empathy atau empati tidak berpengaruh signifikan terhadap kepuasan pelanggan pada bisnis jasa transportasi Grab-Bike dengan t hitung $<\mathrm{t}$ tabel sebesar $0,788<$ 2,005. Besar pengaruh jaminan terhadap kepuasan pelanggan adalah 1,6\%. Hasil pengujian $\mathrm{H} 5$ dalam penelitian ini yang menyatakan bahwa variabel empathy tidak berpengaruh signifikan terhadap kepuasan pelanggan. Jadi dengan demikian H5 ditolak.

5. Hasil Uji Simultan (Uji F)

\begin{tabular}{|cc|c|c|c|c|c|}
\hline \multicolumn{2}{|l|}{ Model } & Sum of Squares & df & Mean Square & F & Sig. \\
\hline & Regression & 1,935 & 5 & 0,387 & 2,534 & 0,039 \\
\hline 1 & Residual & 8,440 & 54 & 0,153 & & \\
\hline & Total & 10,183 & 59 & & & \\
\hline
\end{tabular}

Pada tabel di atas diperoleh bahwa nilai $F=2,534$ dengan tingkat probability $(0,039<0,05)$. Setelah mengetahui besarnya $\mathrm{F}$ hitung maka akan dibandingkan dengan $\mathrm{F}$ tabel. Kemudian dicari pada distribusi nilai $\mathrm{F}$ tabel dan ditemukan nilai $F$ tabel sebesar 2,38. Karena nilai $F$ hitung 2,534 lebih besar dari nilai $\mathrm{F}$ tabel 2,38 maka dapat ditarik kesimpulan bahwa variabel bebas X1, X2, X3, X4, dan X5 (secara simultan) berpengaruh terhadap variabel terikat $(\mathrm{Y})$.

6. Hasil Uji Koefisien Determinasi

\begin{tabular}{|c|c|c|c|c|}
\hline Model & $R$ & $R$ Square & $\begin{array}{c}\text { Adjusted R } \\
\text { Square }\end{array}$ & $\begin{array}{c}\text { Std.Error of the } \\
\text { Estimate }\end{array}$ \\
\hline 1 & 0,436 & 0,190 & 0,115 & 0,391 \\
\hline
\end{tabular}

Dari tabel di atas dapat dijelaskan $\mathrm{R} 2=0,190$ yang berarti menjelaskan besarnya pengaruh tangible, reliability, responsiveness, assurance, dan empathy terhadap kepuasaan pelanggan adalah sebesar $19 \%$ dan sisanya sebesar $81 \%$ dijelaskan variabel lainnya.

\section{Pembahasan}

1. Pengaruh Tangible Terhadap Kepuasan Konsumen Pada Bisnis Jasa Transportasi Grab-Bike.

Hasil penelitian menunjukan bahwa tidak ada pengaruh tangible terhadap kepuasan konsumen pada bisnis jasa transportasi GO-JEK. Hal ini dibuktikan dengan hasil statistik uji $t$ untuk variabel bukti fisik dengan nilai $\mathrm{t}$ hitung sebesar 0,357 dengan nilai signifikansi sebesar 0,722 lebih besar dari 0,05 (0,722>0,05), dan koefisien regresi mempunyai nilai positif sebesar 0,044 . Hal ini menunjukkan bahwa variabel tangible secara parsial tidak ada pengaruh yang signifikan antara variabel tangible terhadap variabel kepuasan konsumen atau dengan kata lain $\mathrm{Ha}$ ditolak. Penilaian masyarakat Yogyakarta selaku konsumen terhadap bukti fisik dari GrabBike tidak berpengaruh terhadap kepuasan yang dirasakan oleh pengguna Grabbike. Mungkin konsumen tidak terlalu memperhatikan tipe kendaraan yang digunakan driver, atribut kendaraan yang diberikan driver, penampilan dan kerapian driver, dan tampilan dari aplikasi Grab itu sendiri. Dengan demikian bukan berarti bukti fisik tidak memiliki pengaruh dengan kepuasan yang dirasakan pelanggan. 
2. Pengaruh Reliability Terhadap Kepuasan Konsumen Pada Bisnis Jasa Transportasi Grab-bike.

Hasil penelitian menunjukkan bahwa ada pengaruh signifikan terhadap kepuasan konsumen pada bisnis jasa transportasi. Hal ini dibuktikan dengan statistik uji $\mathrm{t}$ untuk variabel reliability dengan thitung sebesar 2,692 dengan nilai signifikansi sebesar 0,009 lebih kecil dari 0,05 $(0,009<0,05)$, dan koefisien regresi mempunyai nilai positif sebesar 0,360. Hal ini menunjukkan ada pengaruh yang signifikan antara variabel reability terhadap variabel kepuasan konsumen atau dengan kata lain, $\mathrm{Ha}$ diterima. Kehandalan atau reliability yang diberikan oleh driver mempengaruhi kepuasan yang dirasakan oleh konsumen. Hasil ini memberikan bukti bahwa kehandalan dari penyedia jasa transportasi yang ditunjukkan dalam bentuk ketepatan mengantarkan konsumen, kehandalan driver ketika berkendara, kehandalan aplikasi untuk menghubungkan antara konsumen dan driver dan kehandalan lainnya dalam meningkatkan pelayanan akan sangat berpengaruh dengan kepuasan konsumen.

\section{Pengaruh Responsiveness Terhadap} Kepuasan Konsumen Pada Bisnis Jasa Transportasi Grab-Bike.

Hasil penelitian menunjukan bahwa tidak ada pengaruh responsiveness atau daya tanggap terhadap kepuasan konsumen pada bisnis jasa transportasi Grab-bike. Hal ini dibuktikan dengan hasil statistik uji t untuk variabel daya tanggap dengan nilai $\mathrm{t}$ hitung sebesar 0,334 dengan nilai signifikansi sebesar 0,739 lebih besar dari $0,05(0,739>0,05)$, dan koefisien regresi mempunyai nilai positif sebesar 0,045. Hal ini menunjukkan bahwa variabel responsiveness ssecara parsial tidak ada pengaruh yang signifikan antara variabel responsiveness terhadap variabel kepuasan pelanggan atau dengan kata lain Ha ditolak. Alasan tidak signifikan mungkin dikarenakan konsumen tidak terlalu memperdulikan permasalahan yang terjadi pada aplikasi serta tidak mempedulikan ketepatan waktu pengantaran.

4. Pengaruh Assurance Terhadap Kepuasan Konsumen Pada Bisnis Jasa Transportasi Grab-Bike.

Hasil penelitian menunjukkan bahwa variabel assurance atau jaminan memiliki pengaruh positif akan tetapi tidak berpengaruh signifikan terhadap kepuasan konsumen pada bisnis jasa transportasi Grab-Bike. Hal ini dibuktikan dengan $\mathrm{t}$ hitung sebesar 0,246 dengan nilai signifikansi sebesar 0,807 lebih besar dari 0,05 $(0,807>0,05)$, dan koefisien regresi mempunyai nilai sebesar 0,036 . Hal ini menunjukkan bahwa variabel assurance secara parsial tidak ada pengaruh yang signifikan antara bahwa variabel assurance terhadap variabel kepuasan pelanggan dengan kata lain, Ha ditolak. Alasan tidak signifikan, karena mungkin konsumen beranggapan bahwa pihak Grab-Bike memang sudah seharusnya memberikan rasa aman, nyaman serta profesional saat mengantar pelanggan.

5. Pengaruh Emphaty Terhadap Kepuasan Konsumen Pada Bisnis Jasa Transportasi Grab-Bike.

Hasil penelitian menunjukkan bahwa variabel emphaty memiliki pengaruh positif akan tetapi tidak berpengaruh signifikan terhadap 
kepuasan konsumen pada bisnis jasa transportasi Grab-Bike. Hal ini dibuktikan dengan $\mathrm{t}$ hitung sebesar 0,788 dengan nilai signifikansi sebesar 0,434 lebih besar dari 0,05 $(0,434>0,05)$, dan koefisien regresi mempunyai nilai sebesar 0,106 . Hal ini menunjukkan bahwa variabel emphaty secara parsial tidak ada pengaruh yang signifikan antara variabel emphaty terhadap variabel kepuasan pelanggan dengan kata lain, Ha ditolak. Alasan tidak signifikan karena mungkin konsumen tidak terlalu memperdulikan salam pembuka (selamat pagi/siang/malam) di awal pelayanan, karena bagi konsumen yang penting bisa mengantar konsumen ke tempat tujuan yang diinginkan.

6. Pengaruh Tangible, Reliability, Responsiveness, Assurance dan Emphaty Terhadap Kepuasan Pelanggan Pada Bisnis Jasa Transportasi Grab-Bike.

Hasil penelitian menunjukkan bahwa ada pengaruh tangible, reliability, responsiveness, assurance dan emphaty terhadap kepuasan konsumen pada bisnis jasa transportasi. Hal ini dibuktikan dengan hasil statistic $F$ hitung sebesar 2,534 dengan signifikansi sebesar 0,039. Oleh karena nilai signifikansi lebih kecil dari $\quad 0,05 \quad(0,039<0,05), \quad$ maka penelitian ini berhasil membuktikan hipotesis keenam yang menyatakan bahwa terdapat pengaruh signifikan kualitas pelayanan (tangible, reliability, responsiveness, assurance dan emphaty) terhadap kepuasan pelanggan.

Hasil uji determinan R2 pada penelitian ini diperoleh nilai determinan R2 sebesar 0,190 yang berarti bahwa besarnya pengaruh variabel tangible, reliability, responsiveness, assurance dan emphaty terhadap kepuasan konsumen adalah sebesar $19 \%$ dan sisanya dijelaskan variabel lain yang tidak termasuk dalampenelitian ini.

\section{KESIMPULAN DAN SARAN}

\section{Kesimpulan}

1. Tangible tidak berpengaruh signifikan terhadap kepuasan konsumen Grab Bike. Hal ini dapat dilihat dari hasil uji $\mathrm{t}$ pada variabel tangible dengan nilai hitung sebesar 0,357 lebih kecil dari t tabel dengan nilai 2,005 dan nilai signifikan sebesar 0,722 lebih besar dari $0,05(0,722>0,05)$. Jadi dengan demikian $\mathrm{H} 1$ ditolak.

2. Reliability ada pengaruh signifikan terhadap kepuasan konsumen GrabBike. Hal ini dapat dilihat dari hasil uji $\mathrm{t}$ pada variabel reliability dengan nilai $t$ hitung sebesar 2,692 lebih besar dari $\mathrm{t}$ tabel 2,005 dan nilai signifikan sebesar 0,009 lebih kecil dari $0,05 \quad(0,009<0,05)$. Jadi dengan demikian $\mathrm{H} 2$ diterima.

3. Responsiveness tidak berpengaruh signifikan terhadap kepuasan konsumen Grab-Bike. Hal ini dapat dilihat dari hasil uji t pada variabel responsiveness dengan nilai thitung sebesar 0,334 lebih kecil dari $\mathrm{t}$ tabeldengan nilai 2,005 dan nilai signifikan sebesar 0,739 lebih besar dari 0,05 (0,739>0,05). Jadi dengan demikian $\mathrm{H} 3$ ditolak.

4. Assurance tidak berpengaruh signifikan terhadap kepuasan konsumen GrabBike. Hal ini dapat dilihat dari hasil uji t pada variabel assurance dengan nilai t hitung sebesar 0,246 lebih kecil dari t tabel dengan nilai 2,005 dan nilai signifikan sebesar 0,807 lebih besar dari $0,05(0,807>0,05)$. Jadi dengan demikian $\mathrm{H} 4$ ditolak. 
5. Emphaty tidak berpengaruh signifikan terhadap kepuasan konsumen Grab Bike. Hal ini dapat dilihat dari hasil uji t pada variabel emphaty dengan nilai t hitung sebesar 0,788 lebih kecil dari $t$ tabel dengan nilai 2,005dan nilai signifikan sebesar 0,434 lebih besar dari $0,05 \quad(0,434>0,05)$. Jadi dengan demikian (H5) ditolak.

6. Tangible, Reliability, Responsiveness, Assurance dan Emphaty berpengaruh secara simultan terhadap kepuasan konsumen pada bisnis jasa transportasi Grab-Bike. Hal ini dibuktikan dengan hasilstatistik $\mathrm{F}$ hitung sebesar 2,534 lebih besar dari nilai $\mathrm{F}$ tabel 2,38 $(2,534>2,38)$ dan nilai signifikansi sebesar 0,039. Oleh karena nilai signifikansi lebih besar dari 0,05 $(0,0039>0,05)$.

\section{Saran}

1. Agar dapat memberikan tingkat kepuasan yang tinggi kepada konsumennya Pihak Grab-Bike harus memperhatikan kehandalan yang diberikan, mempertahankan kehandalan dan meningkatkan kualitas layanan dari segi waktu tempuh perjalanan. Karena alasan konsumen memilih Grab-Bike sebagai transportasi adalah waktu tempuh yang diberikan lebih cepat dari angkutan umum. Dalam hal ini pihak Grab-Bikeharus lebih memperhatikan pelayanan dari segi kehandalan (reliability) yang mampu meningkatkan mutu pelayanan GrabBike serta dapat menciptakan kepercayaan konsumen agar konsumen puas dan loyal. Adanya pengaruh dari kualitas kehandalan ini menunjukan bahwa pihak Grab-Bike dapat dipercaya menjaga keselamatan konsumen, mengantarkan konsumen dengan tepat waktu dan konsisten dalam melayani konsumen.
2. Grab-Bike harus tetap memberikan pelayanan yang baik pada dimensidimensi lainnya. Dari segi kualitas fisik Grab-Bike seperti memberikan atribut pendukung saat berkendara seperti masker dan jas hujan. Dari segi kualitas daya tanggap pihak Grab-Bike memberikan informasi yang jelas pada konsumen, dan tanggap dengan pemesanan yang dilakukan konsumen. Dari segi kualitas jaminan, pihak Grab-Bike tetap memperhatikan etika driver saat melayani konsumen seperti memberikan senyuman juga ramah, dan memberikan rasa aman kepada konsumen. Dari segi kualitas empati, pihak Grab-Bike tetap menerima masukan ataupun keluhan dari konsumen ketika mengalami permasalahan pemesanan.

\section{DAFTAR PUSTAKA}

Andreani, Fransisca. (2010). Analisa Kualitas Layanan Bisnis Makanan Dan Minuman Di Surabaya Ditinjau Dari Derajat Pemenuhan Kepuasan Konsumen. Jurnal Manajemen Pemasaran. Surabaya: Universitas Kristen Petra.

Daryanto, \& Setyobudi, I. (2014). Konsumen dan Pelayanan Prima. Malang: Gaya Media.

Ghozali, Imam. (2011). Aplikasi Analisis Multivariate Dengan Program IBM SPSS 19. Semarang: Badan Penerbit Universitas Diponegoro.

Kotler, P., \& Armstrong, G. (2012). Prinsip-Prinsip Pemasaran. Jakarta: Erlangga.

Kotler, p., \& keller, L. (2012). Manajemen Pemasaran jilid 2, edisi ketiga belas, Terjemahan Bob Sabran, MM. Jakarta: Erlangga.

Lupiyoadi, R. (2013). Manajemen Pemasaran Jasa. Jakarta: Salemba Empat. 
Lupiyoadi, R. (2014). Manajemen Pemeasaran Jasa. Jakarta: Salemba Empat.

Marismiati dan Hendra Hadiwijaya. (2013). Pengaruh Kualitas Pelayanan Terhadap Kepuasan Pelanggan Jasa BRT Transmusi Palembang. Jurnal Ekonomi dan Informasi Akuntansi (JENIUS). Vol.3 No.3.

Sanusi, A. (2014). Metodologi Penelitian Bisnis Cetakan ketiga. Jakarta: Salemba Empat.

Sugiyono. (2010). Metode Penelitian Bisnis Pendekatan Kuantitatif, Kualitatif, dan $R \& D$. Bandung: Alfabeta.

Sugiyono. (2014). Metode Penelitian Kombinasi (MIxed Methode). Bandung: Alfabet. 